\title{
Evaluation of the Implementation of the Police Necessary Establishment Education Program (DIKTUKBA) During Covid-19 Pandemic Conditions at the Women Police (SEPOLWAN) School of Police Lemdiklat T.A. 2020/2021
}

\author{
Maria Enny Kryswulandari; Bedjo Sujianto; Siti Rochanah
}

Department of Educational Management, Universitas Negeri Jakarta, Indonesia

http://dx.doi.org/10.18415/ijmmu.v8i12.3281

\begin{abstract}
This study aims to find out and describe comprehensively the implementation and achievement of the objectives of the National Police NCO formation program during the Covid-19 pandemic condition which was carried out at the Women's Police School Lemdiklat Polri T.A. 2020/2021 by looking at the quality of education implementation based on 8 (eight) education standards. The method used is descriptive qualitative and the approach used in this research is evaluation, with the Discrepancy evaluation model developed by Provus. Data collection techniques used observation, interviews, surveys, and documents. As for the results in this study, it is estimated that the effectiveness (success) of parenting is $58.44 \%$. So that the pattern of parenting and guidance still has to be improved, in terms of the methodology of parenting/guidance and competence of caregivers/supervisors, accompanied by the existence of a regular team of motivators.
\end{abstract}

Keywords: Evaluation; Education Program; Covid-19

\section{Introduction}

The dynamics of people's and nations' lives accompanied by advances in information technology and telecommunications have further sharpened the global phenomenon (Farazmand, 2001). The impact of globalization has penetrated various fields of life, both in the economic, social, political, cultural, and educational fields. Education is an important element of human development because education makes a significant contribution to improving welfare through increasing incomes and living standards, increasing abilities, and individual freedom (Kusniati, 2020). Education and technology play a big role in preparing the nation for the future. Education can improve the quality of human resources. The progress of a nation is largely determined by the quality of human resources (Irawan \& Iasha, 2021).

According to the National Education System Law No. 20 of 2003, Education is a conscious and planned effort to create a learning atmosphere and learning process so that students actively develop their potential to have religious-spiritual strength, self-control, personality, intelligence, noble character as well as the skills needed by himself, society, nation, and state (Wahyudiana et al., 2021). In 2019, the Corona 
Virus Disease 2019 (Covid-19) outbreak occurred, this Corona-19 virus not only attacks humans but also has an impact on the world economy and affects social life in various countries (Pudjiastuti \& Hadi, 2020). One of them is in the world of education in Indonesia. Learning that was originally carried out face-to-face is now no longer valid during the COVID-19 pandemic, all done to reduce the spread of the Covid-19 virus in Indonesia (Nur \& Mustaji, 2021). The government takes various ways so that education can continue to run in this pandemic era because education is the main asset for the progress of a country. In the end, the government made a new policy, namely by implementing a learning system from their respective homes, namely online (learning in the network) (Anggraeny et al., 2021). This also has an impact on the implementation of Police education and training.

The National Police of the Republic of Indonesia or commonly called the National Police, as an institution directly responsible under the President, has legal authority and has the main task of maintaining security and public order, enforcing the law, and providing protection, shelter, and services to the community in the context of maintaining security (Undang-Undang Republik Indonesia Nomor 02, 2002). Currently, Polri is in dire need of Polri personnel who can work professionally and proportionally to realize the increasingly strong demands of society for a sense of security and justice. The main task of the National Police is to protect the rights of its citizens and maintain the security and sense of security of the community in carrying out activities to improve their lives.

As protectors, protectors, and public servants, the police are tasked with being a bridge, problem solver, preventing disturbances in public order, inspiration, and motivator in social life (Ekblom, 2013). To realize Polri personnel who are professional and able to meet demands and carry out their main duties well, 3 the Polri will improve itself/transformation by improving aspects, both in structural, instrumental, and cultural aspects. In realizing a law enforcement culture, the National Police seeks to improve the competence of its Human Resources (Kadarmanta, 2008).

Police education is education and training that is carried out in a planned/programmed, directed, measurable, systematic, and sustainable manner, and the results are evaluated periodically to see if they match the plan and the intended profile design and continuously look for opportunities for improvement. Education The formation of the National Police NCO is taken in a short time of 7 (seven) months, but success cannot be measured by how long the education lasts, but the education program carried out must meet the competency standards of graduates. The education has the aim of forming human resources who have certain skills such as negotiation, communication so that they can influence social life and also aim to equip Polri's human resources with the knowledge, skills, and attitudes needed in carrying out their duties in the field (Wahyudiana et al., 2021).

Police candidate education aims to form and develop police candidate personnel who have knowledge, skills, and behavior change. Police candidate education or education for the formation of the National Police NCO has a goal as stated in the educational philosophy of police candidates, namely proficient, commendable, law-abiding, and superior (Izzaty \& Nurfitriani, 2021). Because the initial formation of members of the National Police came from the general public, in this case, the teaching and learning process must be carried out intensively. In organizing police candidate education which is held to realize the competence of the National Police HR, a curriculum and teaching materials (hanjar) are needed as a set of plans and arrangements regarding the objectives, content, and learning materials as well as the methods used as guidelines for organizing learning activities to achieve educational goals in the environment. National Police for National Police Officer candidates (Kadarmanta, 2008).

The purpose of Education for the Establishment of the National Police Officer is to form the National Police Officers who are religious in character, physically and mentally healthy, professional and with integrity in carrying out the duties of the Police. As time goes by, the National Police is making a Transformation towards a Precise Police, to realize all of that, in the implementation of education, the 
formation of the National Police NCO in the coming year has the aim of forming a National Police NCO with a noble character, physically and mentally healthy in carrying out predictive, responsible and transparent police duties. fair (Precision) (Murray, 2007). To support the National Police Chief's policy of transforming towards a Precise Police, there must be teaching materials (hanjar) of national character to create 5 members of the National Police who have a national perspective, love the homeland, are patriotic and helpful.

Police education is an important process in forming Polri human resources to strengthen Polri personnel who will be assigned police duties at all levels of Polri units. Besides that, Polri Education is also a human resource management development which in the implementation of Polri's education and training programs is guided by the principle of integration to implement the education system implemented by the National Education System (Undang-Undang Republik Indonesia Nomor 20, 2003). Within the principle of integration, it can be seen in the Regulation of the National Police Chief Number 6 of 2017 that all the education systems and levels of the National Police are in one institution, namely the National Police Education and Training Institute (Lemdiklat Polri), which leads to a one-stop education system, with the hope that The National Police Education and Training Center will produce candidates for Polri members who are qualified, ready to work, have a tough physical mentality as well as have high productivity, professionalism and performance, and are responsible for work, discipline in their duties, motivation and desire to continuously improve performance, self-disclosure, integrity. morals of honesty and other qualifications (Syakila et al., 2021).

Thus, it can be expected to be able to answer the tasks and challenges of the Police in the present and in the future to the demands of the community, namely the demands of change so that the Police can become friends of the community. Then it can grow a new perspective within the National Police through a change in mindset and culture set, namely the police culture from the militaristic police paradigm to democratic civilian police, upholding the law and human rights so that there will be a harmonious relationship between the police and the community (Kadarmanta, 2008).

The NCO is the front guard who acts as the main executor of police duties who is able to become a communicator for the National Police 6 and the community. Every community that needs police services or assistance will have to deal with the National Police Officer. The NCO consists of men and women. For female police officers, they are usually referred to as female police officers or female police officers. Policewomen (Polwan) are tasked with handling and investigating crime cases involving women, both victims and perpetrators of crimes. The task of policewomen in Indonesia continues to grow, not only regarding crimes against women, children and youth, narcotics and administrative problems, but has even grown to almost equal the various tasks of male police officers. The advantages of Polwan are that they are more humanistic, better in public service, stronger in dealing with bribery and corruption practices and are suitable for cases of women and children (Kadarmanta, 2008).

There should also be no difference in education/training programs between male and female noncommissioned officers, both in terms of physical training and endurance because this will form reliable police candidates and have the same standards (Lagestad \& Van den Tillaar, 2014). In the development of the police candidate program (Bintara) for female police officers (polwan) faced several issues such as gender differences, trustworthiness and so on, which should not be a barrier in providing treatment for female police candidates. With the same treatment as male police officers, they will provide the same quality standard (Bykov, 2014). Providing appropriate treatment in the training/education program for police officers will have a major impact on the ability and resilience of the prospective non-commissioned officers. In a study conducted by giving treatment to the experimental class and the control class, it was found that it showed different results on the resilience and strength of police candidates (Orr et al., 2016). 
Improving the quality of education and training is a systematic, holistic, integrated and comprehensive process with the process of improving the quality of human resources itself. The quality of the 7 graduates of the National Police NCO formation education carried out by the State Education School (SPN) and the Women's Police School (Sepolwan) Lemdiklat Polri, it is not enough to have knowledge and skills competence / proficient (Hard skills) but must be grown and developed values and attitude/behavior (soft skills) which include responsibility for work, discipline in work, motivation and desire to continuously improve performance, self-disclosure, moral integrity, honesty and other qualities (Antariksa, 2021).

Improving students' soft skills with the process of thinking based on personality is very important. By having extensive knowledge of the Police, supported by soft skills in the thought process, it is hoped that the results of graduates can answer the challenges of tasks that are growing every day. So that the results of Polri graduates can be trained to think quickly and precisely in every problem in society (Sunarto, 2015).

In achieving a competency-based Polri education process, it is necessary to have a Polri Profile, a curriculum framework for Polri education, availability of the curriculum, learning process, evaluation process and the presence of adequate and qualified educators and education personnel. In the educational learning process within the National Police Education and Training Institute, the components of educational standards are very necessary, which are regulated in the National Police Chief Regulation Number 14 of 2015, namely: (1) Graduate Competency Standards (SKL) are assessment guidelines in determining student graduation. from the Police Education Unit; (2) Content standards include curriculum and teaching materials (Hanjar) at each type and level of Polri education; (3) The standard process consists of learning and nurturing processes in every Polri education program; (4) Standard Educators and Education Personnel must have academic qualifications, competencies and certifications with duties, authorities and responsibilities; (5) Facilities and infrastructure standards include educational facilities and instructor tools/instructor assistant tools (alins alongins) in each Polri education unit; (6) Management Standards are implemented in 8 stages as follows: planning, organizing, implementing and controlling; (7) Standards for financing the education of the National Police consist of: investment costs and operational costs; (8) Assessment Standards. In order to achieve the strategic objectives of the National Police (Renstra Polri), 13 programs have been established within the Indonesian National Police, one of which is the Police Education and Training Program.

The T.A. Police Apparatus Education and Training Program 2020 has 9 (nine) Police Education Programs including: (1) Police Officer Formation Education Program; (2) Education Program for the formation of the National Police Enlisted Personnel and NCO; (3) Police General Development Education Program; (4) Police Specialization Development Education Program; (5) Polri's Domestic Cooperation Education Program 9 (Kermadagri); (6) National Police's overseas education program; (7) Police Training Program; (8) Centralized Training Program for the Indonesian National Police; (9) Foreign Cooperation Training Program on Police Education and Training (Kep/2502/XII/2019 dated December 23, 2019 regarding the National Police Education and Training Program T.A. 2020). One of these 9 (nine) programs is the National Police Formation Education Program.

The National Police Education and Training Institute (Lemdiklat Polri) is a supporting element under the National Police Chief whose task is to implement strategies for strengthening the field of development, particularly the Human Resources Program to provide personnel through formation and development education. The National Police Education and Training Center has the duty and responsibility to improve the quality of Polri's human resources who are professional, modern, reliable, superior and with integrity and are required to always be able to keep up with the impact of changes in development by optimizing Polri's education. 
One of the work units is the State Police School (SPN) and the Women's Police School (Sepolwan) which are tasked with providing education for the establishment of the National Police as well as other education and training in accordance with the Work Plan (Renja) or the policy of the National Police Chief. The Education Program implemented at the National Police Education and Training Sepolwan in addition to implementing the National Police NCO (Polwan) formation education program also carries out the National Police specialization education program (Dikbangspes Polri).

According to Anam (2018), Polri's education system must be able to produce graduates of Polri personnel who are superior and can keep pace with the progress of an increasingly modern era, have good personalities, and have high spirits. To realize qualified Polri personnel, they must make new breakthroughs by making the Polri Education and Training Institute a center of excellence (center of 10 excellence). The National Police Education and Training Center is expected to be a driving force in efforts to improve Polri's performance to become a superior organization through the creation of quality human resources.

According to Bambang Hendarso Danuri in the Jambi National SPN Profile, he stated that "Jago Negeri Bangum Jaya" Towards the realization of the National Police Education and Training Center as a Center of Excellence stated that: "All Polri educational institutions must also be addressed, then plan changes according to priorities, adjusted to the dynamics of change and the interests of carrying out tasks. It should be understood that cultural change actually starts from educational institutions". (SPN Jambi, 2010). SPN is a Polri educational institution that aims to form Polri personnel who are expected to be able to become lifetime learners who are ready to use, able to contribute positively to society (Anam, 2018).

With the change in the learning system in education for the formation of the NCO during the Covid-19 pandemic, it is also necessary to conduct an evaluation to be able to know and describe comprehensively the implementation and achievement of the educational objectives of the education program for the establishment of the NCO in the context of improvement and refinement for further education, especially during the pandemic.

\section{Research Method}

This study aims to find out and describe comprehensively the implementation and achievement of the objectives of the National Police NCO formation program during the Covid-19 pandemic condition which was carried out at the Women's Police School, Lemdiklat Polri T.A. 2020/2021 by looking at the quality of education implementation based on 8 (eight) education standards. The method used is descriptive qualitative and the approach used in this research is evaluation, with the Discrepancy evaluation model developed by Provus (1973). According to Provus, education programs are dynamic systems that include inputs (antecedents), processes, and outputs (also outcomes). The standards or expectations to be achieved are determined for each of these components. This standard is a program objective which then becomes a criterion in the assessment activities carried out.

According to Arikunto (2020) evaluation research intends to collect data on policy implementation. Thus the benefits of the research results are also for those who make policies. Meanwhile, the 54 program evaluations were one of the objects of evaluation. Programs are activities designed to implement policies. Therefore, this evaluative research is designed using methods that are in accordance with the interests according to the type of data and data sources. 


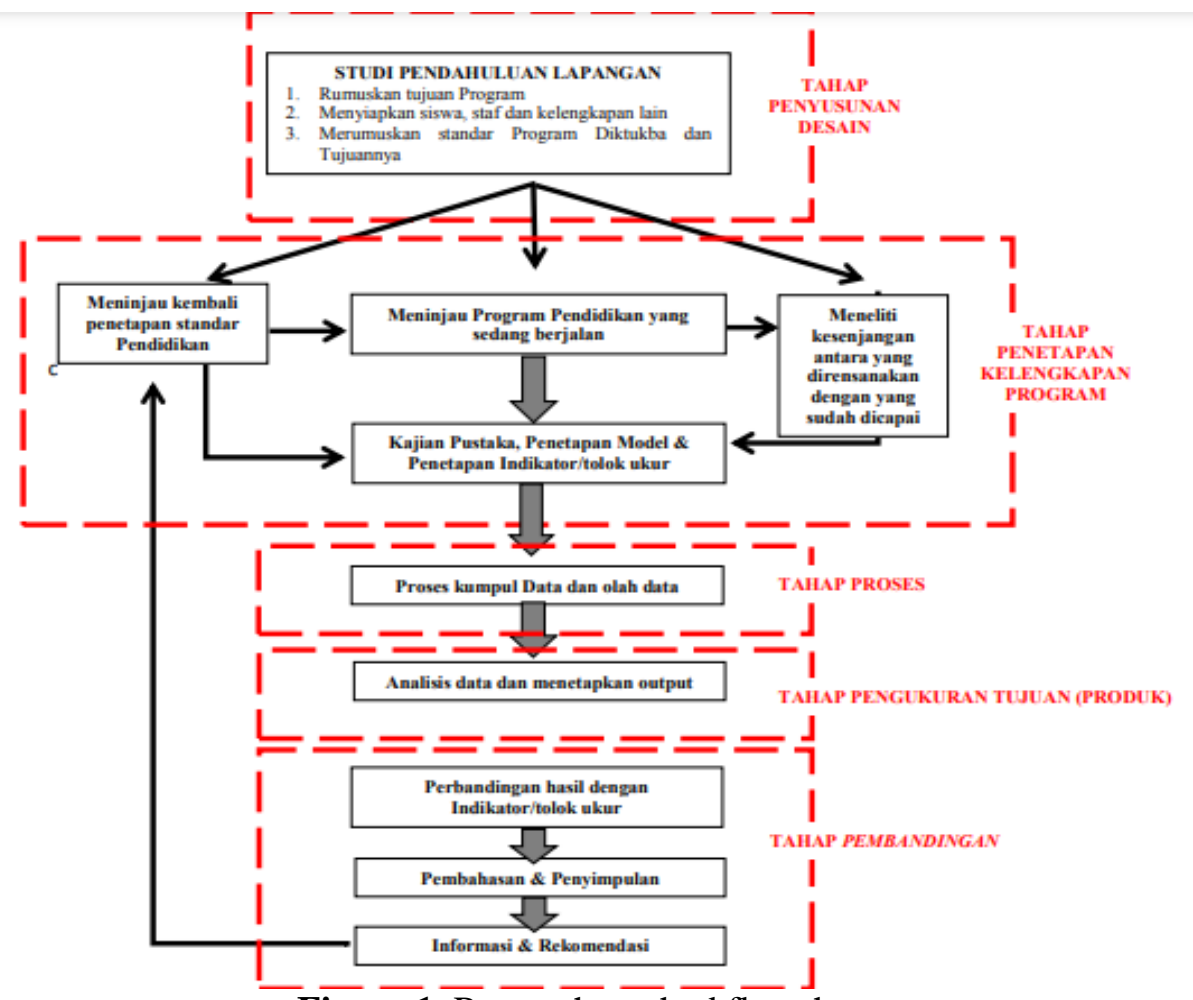

Figure 1. Research method flowchart

The population in this study were Main Officials (Principal of Women Police School (Ka Sepolwan Lemdiklat Polri), Waka Sepolwan Lemdiklat Polri, Head of Training Education Section (Head of Education and Training), Head of Education Personnel Section (Kabag Gadik), Head of Student Development Section (Head of Binsis), Girls and Caregivers in the Sepolwan environment.The respondents are Girls and students of the 2020 National Police Officer Diktuk Diktuk at Sepolwan.

The research instrument was used to assist researchers in the data collection process. In this study, researchers will use non-test instruments in the form of observations, interviews and documentation. This research will be the instrument or research tool is the researcher himself, so the researcher needs to be tested for his understanding and mastery of qualitative research and the field to be studied.

\section{Result and Discussion}

Evaluation activities do not only rely on the assessment of learning outcomes but also assess the input, output and quality of learning outcomes. Thus the meaning of evaluation can provide optimal information and the benefits achieved in the evaluation results of the process of implementing Diktukba on the management of 8 (eight) Polri education standards which include Graduate Competency Standards, Content Standards, Process Standards, Gadik and Gadikan Standards, Infrastructure Standards , Management Standards, Valuation Standards and Financing Standards. Based on the results of student data analysis and questionnaires from students NCO of Polri (Polwan) T.A. 2020-2021.

\section{Graduate Competence Standard}

The highest educational profile of the National Police NCO candidate and the motivation to become a National Police Officer (Polwan), are as follows: 
a. $88 \%$ of candidates for NCO (Polwan) in Sepolwan are graduates of high school/high school, with their age still in the range of 19-21 years, which is the age where emotional control is still unstable. So it takes a lot of guidance, direction and example from seniors, in order to become a professional police officer.

b. $79 \%$ of new non-commissioned parents, have a steady income every month. So it is unlikely that they will be used as the economic foundation of their parents, and make deviations in carrying out their duties as Polri.

c. $73 \%$ of high school graduates enter the police commissioner of their own accord, but do not/do not know about the functions, roles, duties and responsibilities of the police. So that guidance and training to them needs to be carried out progressively and comprehensively.

\section{Content Standard}

In the analysis of the confirmation results that the content standard at Sepolwan Lemdiklat Polri, especially teaching materials, is quite good, for the confirmation value on the content standard achieved is 3.7 including the category of Good Enough, but after interviews and checking documents, several things can be found, among others, still found some Among other things, there are still subjects that are not updated, but some of the contents of the Hanjar are in accordance with the demands of carrying out police duties. For the achievement of $30 \%$ theory and $70 \%$ practice, it is quite maximal due to the Covid 19 pandemic, the learning that was originally planned face-to-face must be changed to Distance Learning (PJJ) so that the curriculum is compressed from $200 \mathrm{JP}$ to $100 \mathrm{JP}$, so the subject matter is not optimal.

\section{Process Standard}

In the analysis of the confirmation results, it is stated that the standard process at the Sepolwan Lemdiklat Polri is getting better. After confirming the interview and checking the documentation, it can be concluded that the process standard reached 3.8 including the Good category. In the answer, after confirmation, it was found in the standard process in connection with feedback and follow-up to the improvement of the learning process, especially during the covid 19 pandemic, not all students can accept learning methods using distance learning information technology (PJJ) due to internet constraints in each region, especially those in the area. live in remote areas. When online learning occurs problems with the internet so that the material obtained is not maximal, there is no maximum feedback because of PJJ.

\section{Graduate Competency Standards (SKL)}

At the analysis stage, the confirmation results stated that the Graduate Competency Standards (SKL) at the Sepolwan Lemdiklat Polri were good. After confirming the interview and checking the documentation, it can be concluded that the competency standard of graduates achieved a score of 4.0 including the Good category. In the answer, after confirmation, it is found in the graduate competency standards that there is an SKL document that can be used as a reference in the implementation of the formation education program.

\section{Standards of Educators and Education Personnel}

The analysis of the confirmation results stated that the standard of Education and Education Personnel in the National Police of the National Police Lemdiklat Sepolwan still needed improvement. After confirming the interview and checking the documentation, it can be concluded that the standard of education and education staff achieved a score of 3.3 including the Enough category. Overall, the achievement of the standards of educators and education personnel, which includes competency assessments that must be possessed by educators, all reached the standard, but in the implementation of the research several things were found, among others, on the one hand, the opinion of educators felt that 
educators were able to carry out educational activities in accordance with their competencies. , but on the one hand there are still students who feel that when educators carry out the teaching and learning process it is still very monotonous and less able to motivate students. There are also opinions of students who are still sleepy in online and face-to-face learning. And there are still educators who feel the need to improve their competence with girl skills training and educator certification, especially if in a situation like today, namely distance learning, educators must have extra skills in the field of computer technology, namely providing learning materials via zoom meetings or google. class.

\section{Standard of Facilities and Infrastructure}

The analysis of the confirmation results stated that the standard of facilities and infrastructure at the Sepolwan Lemdiklat Polri was good. The Sepolwan of Lemdiklat Polri has tried to carry out the prokes optimally, both for health facilities, serdik/dormitory residences including student bathrooms, student study rooms, dining areas and staff rooms for the Sepolwan and the surrounding environment. After confirmation through interviews and checking of documents and facilities, the score obtained was 3.9 in the GOOD category. The standard of infrastructure used by the Sepolwan of Lemdiklat Polri, among others, the capacity of students during the COVID-19 pandemic is insufficient so that it changes the dining room and warehouse into student dormitory in accordance with the Prokes. seat distance, assigning a study chair for each student by giving the student's name/number so that the seat cannot be filled with the names of other students.

\section{Rating Standard}

The analysis of the confirmation results stated that the standard of assessment at the Sepolwan Lemdiklat Polri was good. After confirming through interviews and checking documents, the final score obtained is 4.3 this number is in the Good category. Overall, the achievement of the assessment standard is quite good, in its implementation it has been running optimally. In the standard of assessment which includes aspects of academic, mental personality and physical health. However, in its implementation, several things are still found, including management standards for assessment standards for serdiks covering 3 (three) aspects, namely: Affective, Cognitive and Psychomotor which are used as references by educators in carrying out the task of carrying out the teaching and learning process.

\section{Management Standard}

The analysis of the confirmation results stated that the management standard at the Sepolwan Lemdiklat Polri was getting better. After confirming through interviews and checking documents, the final score obtained is 4.6 this number is in the Better category. Management standards which include annual work plans, planning process, academic regulations and their socialization efforts have been implemented. Availability of Sepolwan management planning within 1 (one) year in the form of Strategic Plan document, annual work plan preparation process document, Renja document and budget preparation (TOR and RAB). The division of tasks, quality assurance, utilization of information technology is available but has not run optimally. Regulations regarding students, awards and sanctions, student administration already exist and are running. The problem that needs to be addressed is that the background of students who are generally educated to become candidates for members of the National Police need guidance, monitoring and exemplary from seniors and leaders need to be carried out intensively and progressively.

\section{Financing Standard}

The analysis of the confirmation results stated that the financing standard at the Sepolwan Lemdiklat Polri was quite good. Based on the results of observations, interviews regarding 8 (eight) 
educational standards in the education program of the T.A. 2020/2021 carried out at Sepolwan Lemdiklat Polri, including content standards, process standards, graduate competency standards, educators and education staff standards, assessment standards, infrastructure standards, management standards and financing standards, in general, have a value of 4.0, namely Good.

\section{Conclusion}

The National Police has made changes in the overall mindset and culture in all police functions. Various efforts have been made by the National Police in realizing these changes, namely the implementation of Education for the Establishment of the National Police Officer. The purpose of the implementation of the education program for the formation of the National Police NCO T.A. 2020/2021 is to form a National Police Officer who is characterized by violence, physically and mentally healthy, professional, and integrated into carrying out the duties of the National Police. It is estimated that the effectiveness (success) of parenting is $58.44 \%$. So that the pattern of parenting and guidance still has to be improved, in terms of the methodology of parenting/guidance and competence of caregivers/supervisors, accompanied by the existence of a regular team of motivators.

\section{References}

Anam, C. (2018). Peningkatan Mutu Tenaga Pendidik SPN (Sekolah Polisi Nasional) guna Menghadapi Tantangan Keamanan Global. Jurnal Ilmu Kepolisian, 12(2), 9.

Anggraeny, I. I., Ekowanti, M. R. L., \& Tamrin, M. H. (2021). Interaction of Policy Actors in Online Learning Implementation. Journal of Governance and Public Policy, 8(3), 184-194.

Antariksa, F. A. (2021). The Effectiveness of Quantum Learning Methods in Group Guidance to Improve Student Motivation in Class VIII A MTS Darul Ulum 2 Widang. Buana Pendidikan: Jurnal Fakultas Keguruan Dan Ilmu Pendidikan, 17(2), 130-137.

Arikunto, S. (2020). Evaluasi program pendidikan.

Bykov, O. (2014). Police academy training: An evaluation of the strengths and weaknesses of police academies. Themis: Research Journal of Justice Studies and Forensic Science, 2(1), 9.

Ekblom, P. (2013). How to police the future: Scanning for scientific and technological innovations which generate potential threats and opportunities in crime, policing and crime reduction. In Crime science (pp. 27-55). Willan.

Farazmand, A. (2001). Globalization, the State and public administration: a theoretical analysis with policy implications for developmental States. Public Organization Review, 1(4), 437-463.

Irawan, S., \& Iasha, V. (2021). Core Learning Model and Mathematical Disposition, Against Mathematics Problem Solving Ability of Elementary School Students. Buana Pendidikan: Jurnal Fakultas Keguruan Dan Ilmu Pendidikan, 17(2), 122-129.

Izzaty, A. D., \& Nurfitriani, M. (2021). Pengembangan Media Pembelajaran Permainan Ludo Pada Materi Operasi Pengurangan Kelas 3 MIS Sindangraja. Buana Pendidikan: Jurnal Fakultas Keguruan Dan Ilmu Pendidikan, 17(1), 33-41.

Kadarmanta, A. (2008). Pendidikan polisi berbasis kompetensi.

Kusniati, T. (2020). Meningkatkan Hasil Belajar Operasi Hitung Bilangan Pecahan Dengan Kartu Bilangan Siswa Kelas VI SDN 3 Mangliawan Kecamatan Pakis Kabupaten Malang. Buana Pendidikan: Jurnal Fakultas Keguruan Dan Ilmu Pendidikan, 16(29), 52-64.

Lagestad, P., \& Van den Tillaar, R. (2014). A comparison of training and physical performance of police students at the start and the end of three-year police education. The Journal of Strength \& Conditioning Research, 28(5), 1394-1400.

Murray, T. (2007). Police-building in Afghanistan: A case study of civil security reform. International Peacekeeping, 14(1), 108-126. 
Nur, N. C., \& Mustaji, M. (2021). Analysis of Student Learning Motivation With Online Learning During the Covid-19 Pandemic. Buana Pendidikan: Jurnal Fakultas Keguruan Dan Ilmu Pendidikan, 17(2), $101-111$.

Orr, R. M., Ford, K., \& Stierli, M. (2016). Implementation of an ability-based training program in police force recruits. Journal of Strength and Conditioning Research, 30(10), 2781-2787.

Pudjiastuti, S. R., \& Hadi, N. (2020). The Effect of Corona Virus on the Global Climate. JHSS (Journal of Humanities and Social Studies), 4(2), 130-136.

Sunarto, M. J. (2015). Improving Students Soft Skills Using Thinking Process Profile Based on Personality Types. International Journal of Evaluation and Research in Education, 4(3), 118-129.

Syakila, S. N. W., Setyowati, W., \& Lestari, D. E. (2021). Independent Learning Program Policies in the Preparation of the Thematic Learning Implementation Plan (RPP). Buana Pendidikan: Jurnal Fakultas Keguruan Dan Ilmu Pendidikan, 17(2), 168-174.

Undang-Undang Republik Indonesia Nomor 02. (2002). Kepolisian Negara Republik Indonesia pasal 13, Lembaran Negara Republik Indonesia tahun 2002.

Undang-Undang Republik Indonesia Nomor 20. (2003). Sistem Pendidikan Nasional.

Wahyudiana, E., Sagita, J., Iasha, V., Setiantini, A., \& Setiarini, A. (2021). Problem-Based LearningBased IPA Practicum Module to Improve Problem-Solving Ability. Buana Pendidikan: Jurnal Fakultas Keguruan Dan Ilmu Pendidikan, 17(2), 161-167.

\section{Copyrights}

Copyright for this article is retained by the author(s), with first publication rights granted to the journal.

This is an open-access article distributed under the terms and conditions of the Creative Commons Attribution license (http://creativecommons.org/licenses/by/4.0/). 